\section{Rubella vaccination and pregnancy: preliminary report of a national survey}

Concern about the number of pregnancies terminated because of vaccination against rubella (257 in 1979-80) prompted the Department of Health and Social Security in 1981 to ask the National Congenital Rubella Surveillance Programme to study the possible teratogenicity of rubella vaccines. Evidence then available from the United States related mainly to Cendehill and HPV77-DE5 vaccines, whereas human diploid vaccine (RA 27/3), which is more immunogenic and reactogenic and therefore possibly more teratogenic, was being widely used in the United Kingdom.

\section{Patients, methods, and results}

Obstetricians have been asked to report women who either conceive within three months after vaccination against rubella or receive vaccine during pregnancy. Clinical and virological follow ups are arranged for women whise pregnancies are not terminated, and their children are followed up until 3 years of age.

By 31 May 1985, 54 mothers had been notified, 35 before and 19 after delivery. Five of them were known to the surveillance programme before the survey started, their infants (all registered as congenital rubella not confirmed) being notified because of the maternal history. Seven of the mothers were vaccinated at school (aged 13-15 years). Thirty four mothers were vaccinated before and 20 after the estimated date of conception. The table gives the mothers' immune state before vaccination related to the strain of vaccine given and the outcome of pregnancy.

All 54 mothers delivered. One aborted spontaneously (virus was not isolated from the placenta, and rubella specific $\operatorname{Ig} M$ was not detected in cord blood). Fifty one mothers delivered liveborn infants and two delivered stillborn infants (one was reported at necropsy as "macerated: no clear cause of intrauterine death"; the other had "no external features of congenital rubella," but permission for necropsy was witheld). Forty four of the 51 liveborn infants, including two with congenital heart defects, were tested for laboratory evidence of congenital infection (presence of rubella specific IgM at birth or persistence of haemagglutination inhibition antibody beyond 8 months, or both). All tests yielded negative results. No clinical evidence of congenital rubella was found in the remaining seven infants at birth, or in three of them followed up at ages ranging from 14 months to 3 years.

\section{Comment}

Although numbers are small, our results are consistent with those of two other continuing studies, both of which started in 1971. Bart et al in the United States reported on 216 infants, and Enders in Germany reported on 98 infants, born to mothers who were susceptible before vaccination. ${ }^{12}$ No infant had the congenital rubella syndrome. Six had laboratory evidence of congenital infection.

Combined data for susceptible women in the United States, Germany, and the United Kingdom give an observed risk of the congenital rubella syndrome of $0 / 335$. The maximum theoretical risk based on the $95 \%$ confidence limits of the binomial distribution is $<1 \%$. The time of vaccination, however, ranges from 12 weeks before to 16 weeks after conception. If the vaccine virus has a teratogenic potential during a very short period of gestation larger numbers of cases will be needed to establish it. Thus current advice regarding rubella vaccination and pregnancy should not be changed. If, however, a woman is vaccinated during pregnancy or becomes pregnant within three months after vaccination she should be carefully and accurately counselled. The risk-if there is one-appears not to be substantial (the term used in the 1967 Abortion Act), and termination of pregnancy should be exceptional under these circumstances. As the infants have the same risk of birth defects as in the general population $(>2 \%)$, and as any defects may be wrongly attributed to the vaccine, full clinical and serological evaluation and reporting to the rubella surveillance programme are crucial.

We thank the obstetricians, paediatricians, and general practitioners who participated in the survey; the Communicable Disease Surveillance Centre; the staff of the Public Health Laboratory Service and National Health Service virus laboratories, especially $\mathrm{Mr}$ George Hawkins, senior chief medical laboratory scientific officer, Hospital for Sick Children, Great Ormond Street, and Dr M H Hambling, consultant virologist, Public Health Laboratory Service, Leeds; and Mr Alan Watkins, statistical assistant, Leeds University. We also thank the Medical Research Council for financial support and Mrs Eileen Wood for preparing the manuscript.

1 Bart SW, Stetler HC, Preblud SR, et al. Fetal risk associated with rubella vaccine: an update. Reo Infect Dis 1985;7 (suppl 1):95-102.

2 Enders G. Rubella antibody titers in vaccinated and nonvaccinated women and rubella vaccination during pregnancy. Rev Infect Dis 1985; 7 (suppl 1):103-7.

(Accepted 13 December 1985

University Department of Paediatrics and Child Health, General Infirmary, Leeds LS2 9NS

SHEILA SHEPPARD, MB, CHB, research fellow

$\mathrm{R}$ W SMITHELLS, MD, FRCP, professor of paediatrics

The Hospital for Sick Children, Great Ormond Street, London WC1N 3JH ANN DICKSON, BA, research assistant

HELEN HOLZEL, MD, MRCPATH, consultant microbiologist

Correspondence to: Dr Sheppard.

\section{Alveolitis after use of a leather impregnation spray}

The use of leather impregnation sprays by the public to protect and give a waterproof finish to leather goods is becoming increasingly widespread. Respiratory distress after the use of such agents has been reported in Germany. We report the development of alveolitis after the use of a leather impregnation spray in the United Kingdom

\section{Case report}

A 17 year old youth with no history of asthma or allergy complained of severe dyspnoea and chest tightness of sudden onset; 15 minutes earlier he had used leather impregnation agent on a pair of shoes. He was brought to the casualty department two hours later. On examination he was obese, pale, and sweaty with a temperature of $38^{\circ} \mathrm{C}$, pulse 120 beats/min, sinus tachycardia, and blood pressure $130 / 80 \mathrm{~mm} \mathrm{Hg}$. Jugular venous pressure was not raised, and heart sounds were normal. His respiratory rate was 44 beats $/ \mathrm{min}$ with poor expansion. Percussion note was normal, breath sounds vesicular, and air entry poor Peak flow rate was $250 \mathrm{l} / \mathrm{min}$, haemoglobin concentration $174 \mathrm{~g} / \mathrm{l}$, white cel count $23.5 \times 10^{9} / 1$, and platelets $240 \times 10^{9} / 1$. Sodium concentration was $139 \mathrm{mmol}(\mathrm{mEq}) / 1$, potassium $4.9 \mathrm{mmol}(\mathrm{mEq}) / \mathrm{l}$, bicarbonate $23 \mathrm{mmol}(\mathrm{mEq}) / 1$ and urea $6.5 \mathrm{mmol} / 1(39 \mathrm{mg} / 100 \mathrm{ml})$. Arterial $\mathrm{pH}$ in room air was $7 \cdot 36$, carbon dioxide tension $4.5 \mathrm{kPa}(34 \mathrm{~mm} \mathrm{Hg})$, oxygen tension $7.9 \mathrm{kPa}(59 \mathrm{~mm} \mathrm{Hg})$, bicarbonate $19 \mathrm{mmol} / 1$, oxygen saturation $90 \%$, base deficit $4.9 \mathrm{mmol}(\mathrm{mEq}) / \mathrm{l}$. An electrocardiogram showed sinus tachycardia, and chest radiography showed widespread patchy changes (figure).

Immune state before vaccination, strain of vaccine given, and outcome of pregnancy

\begin{tabular}{|c|c|c|c|c|c|c|c|c|}
\hline \multirow{2}{*}{$\begin{array}{l}\text { Immune state } \\
\text { before } \\
\text { vaccination }\end{array}$} & \multirow[b]{2}{*}{$\begin{array}{l}\text { No of } \\
\text { women }\end{array}$} & \multicolumn{3}{|c|}{ Strain of vaccine given } & \multicolumn{4}{|c|}{ Outcome of pregnancy } \\
\hline & & RA $27 / 3$ & Cendehill & $\begin{array}{c}\text { Not } \\
\text { known }\end{array}$ & $\begin{array}{l}\text { Live } \\
\text { birth }\end{array}$ & $\begin{array}{l}\text { Infants without evidence of } \\
\text { infection/infants tested }\end{array}$ & Stillbirth & $\begin{array}{l}\text { Spontaneous } \\
\text { abortion }\end{array}$ \\
\hline Susceptible & 23 & 15 & 1 & 7 & $21^{\star}$ & $18^{\star / 18}$ & 1 & $1 \ddagger$ \\
\hline Probably immune & 1 & & & 1 & $1 t$ & $1 / 1$ & & \\
\hline Not known & 30 & 17 & 4 & 9 & 29 & $25 / 25$ & 1 & \\
\hline Total & 54 & 32 & 5 & 17 & 51 & $44 / 44$ & 2 & 1 \\
\hline
\end{tabular}

${ }^{\star}$ Includes one infant with a heart murmur.

tInfant had pulmonary atresia.

$\ddagger$ Rubella virus not isolated from placenta: rubella specific IgM not detected in cord blood. 


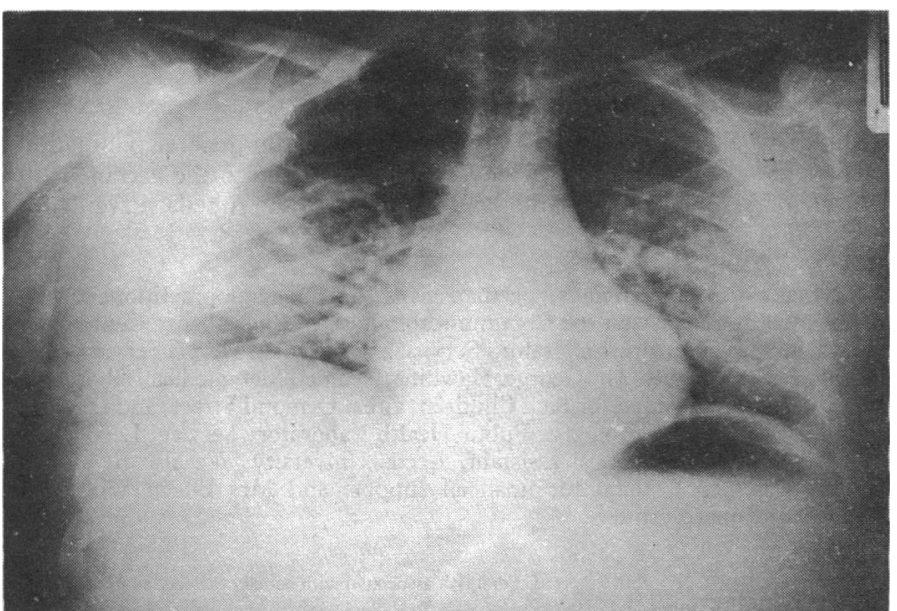

Chest $x$ ray film on admission.

Alveolitis was diagnosed, and he was started on hydrocortisone $200 \mathrm{mg}$ six hourly intravenously and $35 \%$ oxygen by facemask. Twelve hours later he was considerably better. Oral steroids were continued for five days, after which time he was asymptomatic and a chest radiograph was normal.

\section{Comment}

Inhalation of various organic and inorganic substances can cause alveolitis. Pulmonary distress after the use of leather impregnation sprays in homes has been reported in the Federal Republic of Germany. ${ }^{12}$ The development of alveolitis in our patient, however, was intriguing as the previously reported cases occurred at a time when the formulation of the product had been slightly modified, and toxic effects have not been noted since the original formula was reinstated.

The constituent of the spray that is responsible for these effects is difficult to identify: the constituents are not named on the can, and the manufacturer is not able to give further details. The toxicity of the fluorocarbons used as propellants in the aerosols has long been known but usually takes the form of cardiotoxicity. ${ }^{3}$ The active constituents vary in their properties but essentially consist of perfluorocarbon polymers, which are hydrophilic molecules that bind strongly to the substrate. These perfluorocarbon polymers probably also act like a surfactant in the alveolar region." Disruption of the alveolar surfactant is important in the adult respiratory distress syndrome and has been implicated after inhalation of lipid aerosols. ${ }^{5}$

The importance of prompt treatment with steroids was emphasised by Schicht $e t$ al, who described five patients who developed respiratory distress after using leather impregnation sprays. ${ }^{1}$ All five patients had abnormalities of ventilation and diffusion as well as pronounced radiological changes; four had considerable leucocytosis. Pulmonary fibrosis developed in one patien who was untreated but not in the four who received prompt treatment with steroids.

It is important to be aware of this potential toxicity of leather impregnation sprays, which militates against their continued use in the home. Prompt steroid treatment is vital if long term complications are to be avoided.

We thank Dr I D Ramsay, Dr G S Rai, and Mr D Cambridge for guidance and criticisms, and Ms L C Scott, who typed the manuscript.

1 Schicht R, Hartien A, Still V. Alveolitis after inhalation of leather impregnation spray. Dtsch Med Wochenschr 1982;107:688.

2 Okonek S, Reinecke HJ, Fabricius W, Preussner K. Vergiftungen durch Leder-Imprägniersprays. Eine retrospektive Analyseüber 224 Vergiftungsfalle. Disch Med Wochenschr 1983;108:1863-71 3 Belej AM, Aviado DM. Cardiopulmonary toxicity of propellants for aerosols. $\mathcal{J}$ Clin Pharmacol 1975;15:105.

4 Anonymous. Respiratory distress syndrome due to aerosols of organo-fluorine surfactants [Editorial]. Dtsch Med Wochenschr 1972;107:683-4.

5 Fagan DB, Forrest JB. Sudden sniffing death after inhalation of domestic lipid-aerosol. Lancet 1977;ii:361.

(Accepted 30 December 1985)

North Middlesex Hospital, London N18 1QX

G M WRIGHT, BSC, MRCP, medical registrar

A LEE, MB, BS, house officer

Correspondence to: Dr G M Wright, Department of Geriatric Medicine, Whittington Hospital, London N19 5NF.

\section{Serious interaction between cyclosporin $\mathbf{A}$ and sulphadimidine}

Immunosuppression with cyclosporin $A$ is now the treatment of choice in many transplant centres. Though the "window" of therapeutic activity, as assessed by blood concentrations of the drug, is still a matter of debate, it is undoubtedly true that low or undetectable blood concentrations may lead to graft rejection in the early postoperative period. ' We report five cases in which interaction between sulphadimidine and cyclosporin resulted in inadequate cyclosporin immunosuppression. One of these patients has been reported on briefly elsewhere. ${ }^{2}$

\section{Case reports}

Three men and two women aged between 27 and 51 years who had undergone orthotopic cardiac transplantation contracted Pneumocystis carinii pneumonia three to six months postoperatively. Three patients with cough and breathlessness had bilateral inspiratory crackles on auscultation and were hypoxaemic breathing air. Two were asymptomatic with no abnormal examination findings and normal arterial blood gas tensions. All had diffuse bilateral shadowing in chest radiographs. In four patients the diagnosis was confirmed by histological examination of transbronchial biopsy material. In the fifth a rising antibody titre to Pneumocystis was detected.

Each patient had been immunosuppressed with cyclosporin A since operation and on admission was receiving $300-400 \mathrm{mg}$ by mouth twice daily. All had a raised blood urea concentration (mean 15.0 (SEM 1.0) mmol/l; $90 \cdot 4(6 \cdot 0) \mathrm{mg} / 100 \mathrm{ml}$ ) Cyclosporin A was continued and intravenous sulphadimidine $1-2 \mathrm{~g}$ six hourly and trimethoprim $120-800 \mathrm{mg}$ twice daily begun. The dose of trimethoprim was adjusted to maintain a serum trimethoprim concentration between 5 and $10 \mathrm{mg} / 1$. Five to 24 days later (mean 11 days) oral treatment with co-trimoxazole $(80 \mathrm{mg}$ trimethoprim, $400 \mathrm{mg}$ sulphamethoxazole) in a dose of 8-16 tablets daily was substituted for intravenous trimethoprim and sulphadimidine. This dose was also adjusted according to the serum trimethoprim concentration.

Before or shortly after starting intravenous sulphadimidine each patient had a trough serum cyclosporin concentration of $100 \mu \mathrm{g} / \mathrm{l}$ or greater as measured by radioimmunoassay ${ }^{3}$ In four patients this fell to unrecordable values and in one to $40 \mu \mathrm{g} / \mathrm{l}$ within four days (figure). Increasing the dose of cyclosporin A raised the

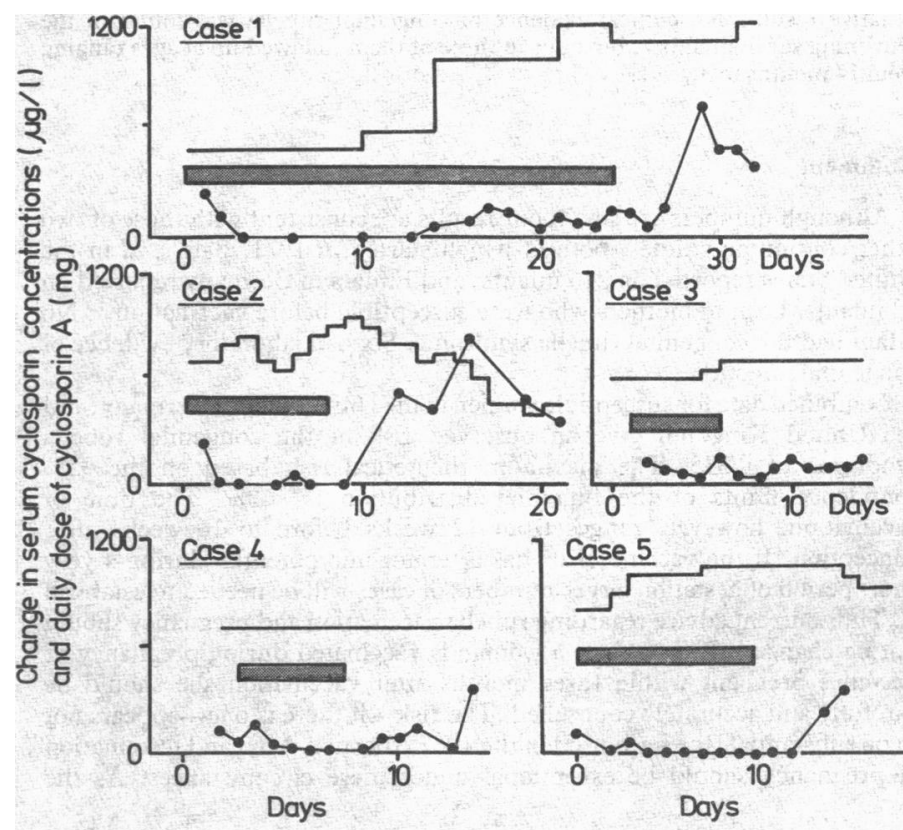

Change in serum cyclosporin concentrations and daily dose of cyclosporin A in days after diagnosis.

Serum cyclosporin concentration. Total daily dose of cyclosporin A. Treatment with intravenous trimethoprim and sulphadimidine.

serum concentrations of this drug in two patients but it was not until intravenous sulphadimidine was stopped that a meaningful recovery in values occurred. In two patients the fall in serum cyclosporin precipitated clinical and histological rejection episodes requiring high dose methylprednisolone. In three patients there was a further small rise in blood urea concentration during treatment but by the time of discharge this had returned to the value on admission. All patients made satisfactory recoveries from their pneumonia and went home two to eight weeks after admission. 